\title{
Economic value of pollination services on crops in Benin, West Africa
}

\author{
Hermann TONI ${ }^{1}$ and Bruno A. DJOSSA ${ }^{1,2^{*}}$ \\ ${ }^{1}$ Laboratoire d'Ecologie Appliquée, Faculté des Sciences Agronomiques, Université d'Abomey-Calavi, Bénin. \\ ${ }^{2}$ Ecole Nationale Supérieure des Sciences et Techniques Agronomiques (ENSTA) de Kétou, \\ Université d'Agriculture de Kétou, Bénin. \\ *Corresponding author, E-mail: djossabruno@gmail.com
}

\begin{abstract}
Pollinators provide pollination services that are crucial for sexual reproduction of many flowering plants. Beside wind and water, pollination services are provided by animals but mainly by insects. They improve the quality and the quantity of many crops. This study aimed at accessing the economic value of pollination services on selected crops in 2010 in Benin. Thus, 29 valued crops were considered and their individual pollination service values obtained from literature. At national scale, the individual gains in production due to pollination services of the selected crops were summed. In this study, all crops used for the calculation require pollination services and their economic added values were estimated to about $99,866.44$ billion of local currency (FCFA) (that equal US \$ 199.21 million) in 2010. This contributes substantially to the economy of Benin (3.03\% of GDP). These results reveal the need to pay more attention to pollinators and their services in agricultural policies definition in Benin. We suggest a rational use of pesticides in agriculture and the preference of traditional practices in agriculture such as the preservation of few native plants in farming areas to give opportunity to conserve pollinators in these areas.
\end{abstract}

(c) 2015 International Formulae Group. All rights reserved.

Keywords: Added value, agriculture, conservation, pollinators.

\section{INTRODUCTION}

Plants and crops are very useful for human, animals and their environment/habitats. Their different organs are exploited for human and animals nutrition, for disease treatment, in house building and in many activities. The majority of these plants and crops need pollinators' services for their sexual reproduction. Pollinators provide an essential ecosystem service that result in the out-crossing and sexual reproduction of many plants (Eardley et al., 2006). They contribute to conserve natural ecosystem and biological diversity. Over $80 \%$ of flowering plants are pollinated by animals mainly by insects (Kevan and Imperatriz-Fonseca, 2002; FAO, 2009). These pollinators are butterflies, bats, birds, beetles, flies and bees which contribute heavily to plant pollination in the tropics and subtropical parts of the world (Crane, 1992; Williams, 1994; Tim, 1999). Approximately $73 \%$ of the world's cultivated crops are pollinated by some variety of bees (Pollinator Diversity, 2004). Among those, the honey bee (Apis mellifera) is the principal species used for crop pollination worldwide (Free, 1993). Pollinators provide several services to humans through increasing crop yield ensuring food 
security. Their effect on crops may hence be quantitative and qualitative. 87 of the 124 single crops grown in the world increase their production with pollinating animals services (Klein et al., 2007). Similar results have been reported for many crops grown in the world (Carlos et al., 1998; Pando et al., 2011; Chang et al., 2011; Sarah et al., 2006). Quality and quantity of crops production are clearly positively affected by pollination services (Chautá-Mellizo et al., 2012) and wild and honey bees are complementary in pollination services (Ghazoul et al., 2013). Pollinators thereby enhance the economic profits (Garratt et al., 2014). Despite the importance of pollinators, their populations decrease in many regions of the world (FAO, 2008) due to human activities like agricultural and industrial chemicals, diseases, parasites, habitat loss, imported pollinators and fragmentation (Freitas, 2004). This situation will be very harmful for humanity particularly for African countries where economy largely depends on agriculture and natural resources exploitation. It might also have severe consequences for the farmers themselves (Eisikowitch, 2004).

In order to value pollinator's importance within landscape and for human, investigations have been done worldwide for many years to evaluate their economic value. It was then demonstrated that crop pollination by bees and other animals is an ecosystem service which has a great economic value (Allsop et al., 2008; Losey and Vaughan, 2006). Different methods have been proposed to evaluate the economic value of pollinators depending on the case. According to Bauer and Wing (2010), there are five methods.

The first category contains studies that value the pollination services provided by managed, commercially-available bee colonies. The second category of pollination valuation uses an approach that calculates the value of total annual crop production that can be directly attributed to animal pollination. The third category of valuation measures the economic value of pollination as the sum of the changes to producer and consumer surplus induced by the decrease in production due to a loss of pollination services (Kevan and Phillips, 2001). The fourth type of analysis estimate the costs of other market-based pollination alternatives involving labour (hand pollination) or capital (mechanized pollen dusting) that would be needed to maintain the level of crop production at that specific level provided by animal pollinators (Allsop et al., 2008). In the final category of pollination valuation, a landscape-based approach is used to value wild pollinator habitat. Its objective is to relate the characteristics of habitat fragments to crop yields (Morandin and Winston 2006; Oleschewski et al., 2006; Ricketts et al., 2004).

These different methods have been used to estimate the pollination value in some countries such as USA (Morse and Calderone, 2000), France (Borneck and Bricout, 1984), United Kingdom (Carreck and Williams, 1998), Australia (Gordon and Davis, 2003), and New Zealand (Gibbs and Muirhead, 1998). However, no study concentrated on pollination value was yet conducted in Benin. In this climate change context and manmade threats on pollinators, it becomes relevant to evaluate their economic value in order to point out their contribution on countries income. Estimating even a minimum value for a subset of the services that functioning ecosystems provide may help establish a higher priority for their conservation (Losey and Vaughan, 2006). This work accessed the economic value of pollinators in Benin and thus the economic losses that would be experienced in case of pollinators' decline. It aims at contributing to document the economic value of the pollination services provided my unmanaged pollinators in order to raise awareness in local communities but also for management decision making in agriculture.

\section{MATERIALS AND METHODS \\ Study area}

The study has been conducted on Benin, a tropical, sub-Saharan country situated between $6^{\circ} 30^{\prime}$ and $12^{\circ} 30^{\prime} \mathrm{N}$ (Figure 1). The country covers 114763 square kilometres with a population estimated to 7 356756 inhabitants in 2008. Four major groups of soils can be distinguished: ferrallitic soils covered by semi-deciduous forest, 
ferruginous soils covered by dry forest, woodland, and savannah, vertisol in the depression of Lama covered by a particular dry type of semi-deciduous forest, and hydromorphic soils covered by swamp and riparian forests (Adomou, 2005). The annual rainfall varies between 900 to $1300 \mathrm{~mm}$ with four seasons in south-Benin and two in the north. The main activity of the rural population is agriculture.

\section{Economic value calculation}

This study aims at estimating the economic value of pollination services in Benin during year 2010. Thus, 29 relevant value crops were selected. These crops are distributed in three groups: field crop, vegetable crops and fruits and nut. The added value (economic value) due to pollination services was calculated following the formula used by different authors (Levin, 1984; Carreck and Williams, 1998; Morse and Calderone, 2000):

\section{$E V P=\sum D_{i} \times Q_{i} \times P_{i}$}

Where EVP is the economic value due to pollination, $D_{i}=$ the dependency of each crop on pollinators, $P_{i}=$ the price of each crop and $Q_{i}=$ the quantity produced for each crop $i$

This method is used because it helps to estimate the value of the pollination service at the national scale (FAO, 2006).
Information about economic value of plants was collected from the literature mainly from FAOSTAT. These values expressed in US dollar were converted in the local currency (FCFA). The dependence of each plant on pollinators' activities was also obtained from the literature. According to Klein et al. (2007), the dependence of plant to pollinator's services and successful fruit and seed setting varies from one crop to another. This ratio was calculated base on the impact of pollinator's absence on crops yield. For this work, four categories of plant were used: $i$ ) plants which depend lightly on pollinator (0$10 \%$ of yield); ii) plants which depend modestly on pollinators $(10-40 \%)$; iii) plants which depend greatly on pollinators and $i v$ ) plants for which pollinators are essential (more than $90 \%$ needed).

For pollination value estimation, the midpoints of these ranges: 5, 25, 65 and 95 were used respectively.

At the end, the value estimation of individual crops was summed to get the global economic value of pollination services on the selected crops in 2010 for Benin. The calculations were done in Excel Microsoft 2007.

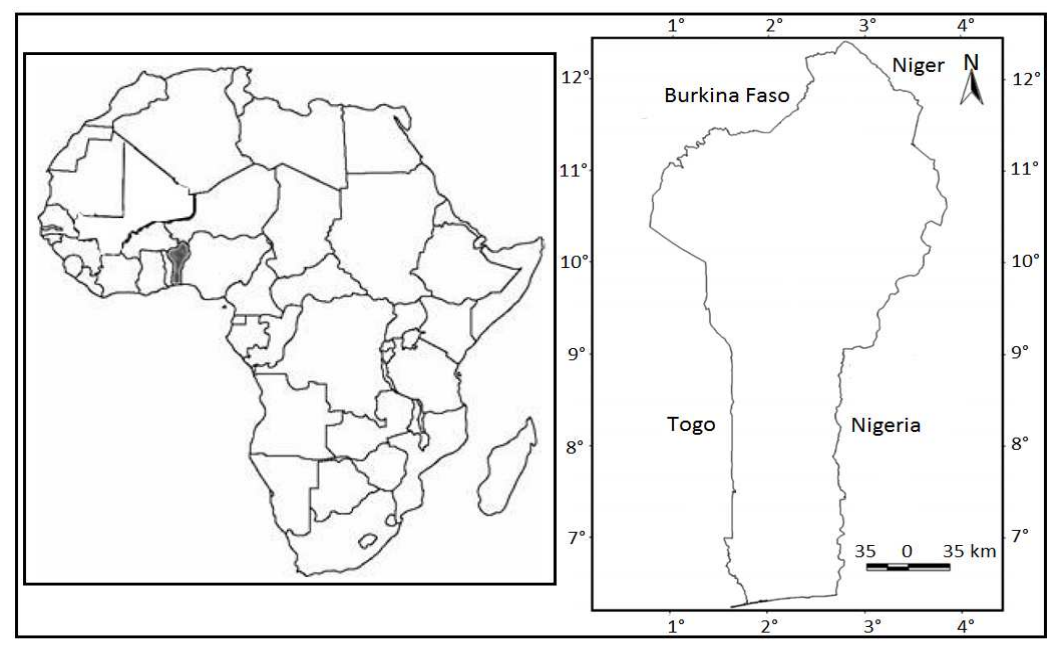

Figure 1: Map of Benin and Africa map showing Benin position. 


\section{RESULTS}

Table 1 presents the crops with their cash produced for Benin in 2010. According to FAOSTAT (2011) followed by economic value of pollination services (EVP), we calculated that mean with the added value. These estimated values show the monetary losses that should be engendered by pollinator's lack.

Table 1: Economic value of pollination services in 2010 for Benin.

\begin{tabular}{|c|c|c|c|c|}
\hline Crops & Scientific name & Pollination effect & $\begin{array}{c}\text { Cash per } \\
\text { crop (million } \\
\text { of FCFA) } \\
\end{array}$ & $\begin{array}{c}\text { Pollination added } \\
\text { value (million of } \\
\text { FCFA) }(\%)^{*}\end{array}$ \\
\hline Banana & Musa spp. & $\begin{array}{c}\text { Breeding potential } \\
\text { / fruit }\end{array}$ & 2661,22 & $133,06(5)$ \\
\hline Bitter apple & Citrullus colocynthis & seeds & 27,82 & $26,43(95)$ \\
\hline Black pepper & Piper nigrum & seeds & 174,82 & $8,74(5)$ \\
\hline Cashew nut & $\begin{array}{l}\text { Anacardium } \\
\text { occidentale }\end{array}$ & fruit and nut & 32029,72 & $20819,32(65)$ \\
\hline Cassava & Manihot esculenta & breeding potential & 227456,25 & $11372,81(5)$ \\
\hline Castor-oil plant & Ricinus communis & seeds & 122,85 & $6,14(5)$ \\
\hline Chillies & Capsicum spp. & fruit & 16447,72 & $822,39(5)$ \\
\hline Cocoa & Theobroma cacao & fruit & 54,6 & $51,87(95)$ \\
\hline Coconut & Cocos nucifera & nut & 998,55 & $249,64(25)$ \\
\hline Cola nut & Cola nitida & nut & 204,75 & $133,09(65)$ \\
\hline Cotton/ lint & Gossypium spp. & fibre & $57,250.2$ & $14,312.55(25)$ \\
\hline Cotton/ seed & Gossypium spp. & Seeds & $17,968.12$ & $4,492.03(25)$ \\
\hline Cowpea & Vigna unguiculata & seeds & 51306,68 & $2565,33(5)$ \\
\hline Groundnuts & Arachis hypogaea & seeds & 27711,6 & $1385,58(5)$ \\
\hline Irish potato & Solanum tuberosum & breeding potential & 3,68 & $0,18(5)$ \\
\hline Karite & Vitellaria paradoxa & nut & 916,65 & $229,16(25)$ \\
\hline Maize & Zea mays & seeds & 91919,1 & $4595,96(5)$ \\
\hline Mango/guajava & $\begin{array}{l}\text { Mangifera indical } \\
\text { Psidium guajava }\end{array}$ & fruit & 4309,72 & $2801,32(65)$ \\
\hline Okra & $\begin{array}{l}\text { Abelmoschus } \\
\text { esculentus }\end{array}$ & fruit & 13395,9 & $3348,98(5)$ \\
\hline Onion & Allium сера & seeds & 3539,55 & $3362,57(95)$ \\
\hline Orange & Citrus sinensis & fruit & 1359,75 & $67,99(5)$ \\
\hline Pineapples & Ananas comosus & seeds & 33042,45 & $1652,12(5)$ \\
\hline Potato & Ipomoea batatas & breeding potential & 2458,575 & $122,93(5)$ \\
\hline Sesame & Sesamum indicum & seed & 3553,72 & $888,43(25)$ \\
\hline Soybean & Glycine $\max$ & seeds & 2304,22 & $576,06(25)$ \\
\hline sweet pepper & Capsicum frutescens & fruit & 6178,72 & $308,94(5)$ \\
\hline Taro & Colocasia esculenta & breeding potential & 256,2 & $12,81(5)$ \\
\hline Tomato & $\begin{array}{l}\text { Lycopersicon } \\
\text { esculentum }\end{array}$ & fruit & 29995,88 & $7498,97(25)$ \\
\hline Yam & Dioscorea spp & breeding potential & 320003,25 & $16000,16(5)$ \\
\hline Total & & & 904586,52 & 99866,44 (11) \\
\hline
\end{tabular}


The table shows a range of 5 to $95 \%$ of added values. Crops such as onion and bitter apple (goussi) had the highest EVP (95\%) followed by cola nut tree, cashew tree $(65 \%)$, sesame, soya been, tomato, etc. (25\%) whereas the smallest EVP was obtained for fruits and nuts like okra, orange, pineapples, etc. (5\%). For added value, the highest amounts were recorded for cashew nut (20819.32 million), cotton lint and seed (18804.58 million) and yam (16000.16 million). These crops are produced in the whole country in large quantity contributing meaningfully to the country's economy. Cashew and cotton are among the major exported crops on which the whole country economy depends. Lower added values were reported for crops such as Irish potato, castoroil plant and black pepper which depend lowly on pollinator's services.

\section{DISCUSSION}

Many plants need animal pollination services and their production successes are directly correlated with the quantity and the quality of these pollination services. The present study that reports on the contribution of the animal pollination services to different crops revealed that pollinators are needed for many crops grown in Benin. Pollinators then contributed greatly to crop production in Benin in 2010. This is due to the increase of area devoted to pollinator-dependent crops (Aizen, 2008). In fact, during this last decade, the production of some crops such as yam, cassava, pineapple and palm fruit has increased because of the yields improvement and agricultural area extension (MEF, 2011). Crops which do not depend on animal pollination are essentially Gramineae that are generally wind pollinated (McGregor, 1976; Tchuenguem, 2002).

Added values due to pollination services were substantial for the economy of a developing country like Benin in 2010. This value represents $3.03 \%$ of Beninese Gross Domesticated Product (GDP) estimated by World Bank to reach US \$ 6.55 billion in 2010. Similar results were reported for USA (Morse and Calderone, 2000), Australia (Gordon and Davis, 2003), Canada (Oliveira, 2005) and Egypt (Brading et al., 2009) supporting the meaningful role played by these pollinators even though the added value vary from one country to another. The number of crops used for the calculation and their yields could affect the added values explaining the differences observed between countries. For instance, many of crops used for calculation in USA and Canada are fully dependent on animal pollination services compared with the situation in the present study where only few $(7 \%)$ are fully dependent to animal pollination services.

Other parameters to be considered are the quality of habitat and environment quality that could be favourable for animal pollination services expression. As a confirmation, Ricketts et al. (2004) reported 20.8\% higher yield in coffee plants situated at the edge of forest compared with those situated in the centre of the field far from forest. This situation raises the problem of the impact of habitat fragmentation which is very harmful to pollinators. It leads to the reduction of pollinators within disturbed habitats (González-Varo et al., 2009) and to pollination failure (Wilcock and Neiland, 2002). Segal et al. (2006) stressed that fragmentation may link the effects of inbreeding depression and pollinator activity to generate a "pollination crisis", expressed as significant reduction in sexual reproduction.

In another hand, agricultural practices in agro-systems could also affect pollinators and their services. In Benin, farmers who are in majority not trained at technical schools pay almost no attention to insects when comes 
to apply agrochemicals in their farms, moreover, sometime the quantity to be applied per hectare is not respected. It was recognized that these chemical pollutants contribute to pollinator's decline (Freitas, 2004).

Pollination contribution on Beninese economy in 2010 was estimated to FCFA 99866,44 billion but, it should be more important because only few cultivated crops were targeted for the present study. We didn't take into account some wild neglected crops which are however heavily collected and used by rural communities such as Borassus aethiopum, Parkia biglobosa, Adansonia digitata, Tamarindus indica, etc. (Atchoua et al., 2009) that are also of high economic value in Benin. The data deficiency situation couldn't allow considering them although they also rely on animal pollination too for fruits and seeds production (Costanza et al., 1997). In addition, the aesthetic value of pollination to ornamentals, wild flowers, and forest and range plants in terms of beauty of the landscape is recognized for specific plants but it cannot be measured too (FAO, 2008). The crop dependence on pollinators is somehow site or area specific that why different authors used different ration of this pollination services for the same crop from one area to another (Morse et al., 2000; Pouvreau, 2004; De Oliveira, 2005). Due to these differences, Klein et al. (2007) recommended to calculate this ratio on specific area for a given crop avoiding a generalizing use of pollination service dependence ratio. Until now, few studies were carried out in Benin to measure impact of pollinators on crops yields. So, the dependence ratio of crops on pollinators used for calculation was obtained from studies carried out in others countries which have a similar climate. This situation suggests that we take the values presented in this paper with caution although they fully showed the importance of the contribution of pollinators to the different crop productions and thereby the added estimated economic values in Bénin for 2010 .

Agriculture contributes to the third of Benin's GDP and provides work to $60 \%$ of Beninese (World Bank; BAFD/OECD, 2008). During the last 20 past years cotton production is increasing with heavy use of pesticides mainly in the northern Benin. In light of the results of this work that revealed the importance of pollination services for key crops and in turn to Benin agriculture's contribution to its economy, pollination services delivery can be seriously affected by pollinators decline due to agrochemicals' pollution and this is likely to impact negatively food security consideration mainly in poor rural communities.

\section{Conclusion}

Pollinators are needed for many crops grown in Benin on which depends its economy. The contribution of pollinators in crop production should increase in the near future because of the increase of crop production which is necessary to sustain the growth of the population of Benin. Therefore, pollinators need to be conserved to guaranty the services they provide to the cropping system. Agriculture policies must integrate pollinators as important production factor and work to their conservation and valorisation. In addition, the use of pesticides and others agrochemicals harmful to pollinators must be treated carefully. In addition, we suggest that similar to practices in farming systems in developed countries, we start considering honey bee colonies used to support in complementary to wild pollinators. The pollination services that we showed here is very important for food production in Benin.

\section{REFERENCES}

Adomou CA. 2005. Vegetation Patterns and Environmental gradients in Benin. Implications for biogeography and 
conservation. $\mathrm{PhD}$ Thesis, Wageningen University, Wageningen, $\mathrm{p} 133$.

Aizen MA, Garibaldi LA, Cunningham SA, Klein AM. 2008. Long-term global trends in crop yield and production reveal no current pollination shortage but increasing pollinator dependency. Curr Biol., 18:1-4.

Allsop MH, De Lange WJ, Veldtman R. 2008. Valuing insect pollination services with cost replacement. Plos One, 3:e3128.

Atchoua M, Tohou F, Amoussou LA. 2009. Etude sur l'Identification des Possibilités de Valorisation Durable des Produits Forestiers Non Ligneux dans les Périphéries du Parc National du $w$ au Benin. Groupe d'Etude, de Suivi et de Réalisation des Initiatives de Développement : Benin.

BAFD/OCDE 2008. Perspectives économiques en Afrique - Bénin. Banque Africaine de Développement / Organisation de Coopération et de Développement Economiques. http://www.oecd.org/dataoecd/3/52/4056 8777.pdf.

Bauer DM, Wing IS. 2010. Economic Consequences of Pollinator Declines: A Synthesis. Agr. Resource Econ. Rev., 39: 368-389.

Borneck R, Bricout JP. 1984. Evaluation de l'incidence économique de l'entomofaune pollinisatrice en agriculture. Bulletin Technique Apicole, 11: 117-24.

Brading P, El-Gabbas A, Zalat S, Gilbert F. 2009. Biodiversity Economics: The Value of Pollination Services to Egypt. Egyptian Journal of Biology, 11: 46-51.

Carreck NL, Williams IH. 1998. The economic value of bees in the UK. Bee World, 79: 115-123.

Chautá-Mellizo A, Stuart A. Campbell, Maria Argenis Bonilla, Jennifer S. Thaler, Katja Poveda. 2012. Effects of natural and artificial pollination on fruit and offspring quality. Basic and Appplied Ecology, 13(6): 525-532.

Crane E. 1992. The past and present status of beekeeping with stingless bees. Bee World, 73: 29-42.

De Oliveira D. 2005. Évaluation économique de l'abeille domestique, en 2005, au Québec. Congrès SEQ, 2005.

Eardley C, Roth D, Clarke J, Buchmann S. Gemmill B. 2006. Pollinators and Pollination: a Resource Book for Policy and Practice. African Pollinator Institute: Pretoria.

Eisikowitch D. 2004. Modern agriculture and nature conservation: an unsolved conflict. Tropical Beekeeping: Research and Development for Pollination and Conservation Conference 22-25 February, San José, Costa Rica.

FAO. 2006. Tools for conservation and use of pollination services. Economic valuation of pollination services: Review of Methods, FAO.

FAO. 2008. Rapid assessment of pollinators' status a contribution to the international initiative for the conservation and sustainable use of pollinators, FAO.

FAO. 2009. Les pollinisateurs: un élément négligé de la biodiversité, important pour l'alimentation et l'agriculture, FAO.

FAO. 2010. FAOSTAT. Available at http://faostat.fao.org/DesktopDefault.aspx ? Page ID=339 \&lang=fr

Free JB. 1993. Insect Pollination of Crops (2nd edn). Academic Press: London UK.

Freitas BM, Otávio JP. 2004. Pereira solitary bees conservation, rearing and management for pollination. A contribution to the International Workshop on Solitary Bees and Their Role in Pollination, Brazil.

Garratt MPD, Breeze TD, Jenner N, Polce C, Biesmeijer JC, Potts SG. 2014. Avoiding a bad apple: Insect pollination enhances fruit quality and economic value. 
Agriculture, Ecosystems and Environment 184: 34-40.

Ghazoul J. 2005. Business as usual? Questioning the global pollination crisis. Trends Ecol. Evol., 20: 367-373.

Gibbs D, Muirhead I. 1998. The economic value and environmental impact of the Australian beekeeping industry. A report prepared for the Australian Beekeeping Industry 30.

Gnimadi A. 2008. Etude pour l'identification des filières agroindustrielles prioritaires (Benin). Mission $\quad \mathrm{N}^{\circ} \mathrm{TE} / \mathrm{RAF} / 07 /$ A01-1751-2008.

González-Varo JP, Arroyo J, Aparicio A. 2009. Effects of fragmentation on pollinator assemblage, pollen limitation and seed production of Mediterranean myrtle (Myrtus communis). Biological Conservation, 142: 1058-1065.

Gordon J, Davis L. 2003. Valuing honeybee pollination. Rural Industries Research and Development Corporation Paper 03/077, Canberra: ACT, Australia.

Kevan PG, Phillips TP. 2001. The economic impacts of pollinator declines: an approach to assessing the consequences. Conserv. Ecol., 5: 8.

Latif A, Qayum A, Abbas M. 1960. The role of Apis indica in the pollination of toria (Brassica napus) and sarson (B. campestris). Bee World, 41: 283-286.

Losey JE, Vaughan M. 2006. The economic value of ecological services provided by insects. Bioscience, 56(4): 311-323.

Luo CW, Huang ZY, Chen XM, Li K, Chen Y, Sun Y. 2011. Contribution of diurnal and nocturnal insects to the pollination of Jatropha curcas (Euphorbiaceae) in south western China. Journal of Economic Entomology, 104(1): 149-154.

Mcgregor SE. 1976. Insect Pollination of Cultivated Crop Plants: Agriculture Handbook $496 . \quad$ USDA-ARS : Washington DC.
MEF (Ministère de l'Économie et des Finances). 2011. Situation des principales productions agricoles en République du Bénin. http://www.tresor.economie. gouv.fr/3308_situation-des-principalesproductions-agricoles-en-republique-dubenin

Morandin LA, Winston ML. 2006. Pollinators provide economic incentive to preserve natural land in agroecosystems. Agriculture, Ecosystems \& Environment, 116: 289-292.

Morse RA, Calderone NW. 2000. The value of honey bees as pollinators of U.S. crops in 2000. Bee Culture, 128(3): 1-15.

Olschewski R, Tscharntke T, Benitez PC, Schwartze S, Klein AM. 2006. Economic evaluation of pollination services comparing coffee landscapes in Ecuador and Indonesia. Ecology and Society, 11: 7.

Pando JB, Tchuenguem F, Tamesse JL. 2011. Pollination and yield responses of pigeon pea (Cajanus cajan L. Mill sp.) to the foraging activity of Chalicodoma cincta cincta (Hymenoptera: Megachilidae) in Yaoundé (Cameroon). Journal of Animal \& Plant Sciences, 11(1): 1346-1357.

Pouvreau A. 2004. Les Insectes Pollinisateurs. Edition Delachaux and Niestlé: Paris.

Richards AJ. 2001. Does low biodiversity resulting from modern agricultural practice affect crop pollination and yield? Ann. Bot., 88: 165-172.

Ricketts TH, Daily GC, Ehrlich PR, Michener CD. 2004. Economic value of tropical forest to coffee production. Proceedings of the National Academy of Sciences, 101: 12579-12582.

Segal B, Sapir Y, Carmel Y. 2006. Fragmentation and pollination crisis in the self-incompatible Iris bismarckiana (iridaceae), with implications for 
conservation. Israel Journal of Ecology \& Evolution, 52: 111-122.

Tchuenguem F, Messi J, Pauly A. 2002. L'activité de butinage des Apoïdes sauvages (Hymenoptera Apoidea) sur les fleurs de maïs à Yaoundé (Cameroun) et réflexions sur la pollinisation des graminées tropicales. Biotechnol. Agron. Soc. Environ., 6(2): 87-98.

Tim AH. 1999. The role of stingless bees in crop pollination. Annu. Rev. Entomol., 44:183-206.
Wilcock C, Neiland R. 2002. Pollination failure in plants: why it happens and when it matters. Trends in Plant Sciences, 7: 270-277.

Williams IH. 1994. The dependence of crop production within the European Union on pollination by honey bees. Agricultural Science Reviews, 6: 229-257. 